\title{
VIPR1 wt Allele
}

National Cancer Institute

\section{Source}

National Cancer Institute. VIPR1 wt Allele. NCI Thesaurus. Code C51482.

Human VIPR1 wild-type allele is located within 3p22 and is approximately $48 \mathrm{~kb}$ in length.

This allele, which encodes vasoactive intestinal polypeptide receptor 1 protein, plays a

role in intercellular communication and adenylate cyclase activation. 